\title{
Angiotensin II does not stimulate proliferation of rat thyroid PC Cl3 cell line
}

\author{
Simona Romano, Antonella Muscella, Carlo Storelli and Santo Marsigliante \\ Department of Biological and Environmental Sciences and Technologies, Ecotekne, Via Prov.le per Monteroni, 73100 Lecce, Italy \\ (Requests for offprints should be addressed to S Marsigliante who is now at Laboratorio di Fisiologia Cellulare, Dipartimento di Scienze e Tecnologie Biologiche \\ e Ambientali, Università di Lecce, Via Provinciale per Monteroni, 73100 Lecce, Italy; Email: santo.marsigliante@unile.it)
}

\begin{abstract}
In $\mathrm{PC} \mathrm{Cl3} \mathrm{cells,} \mathrm{a} \mathrm{rat} \mathrm{thyroid} \mathrm{cell} \mathrm{line,} \mathrm{angiotensin} \mathrm{(Ang} \mathrm{II)}$ activates the atypical protein kinase $\mathrm{C}-\zeta(\mathrm{PKC}-\zeta)$ and the extracellular signal-regulated kinase (ERK) pathways. We here studied the Ang II effects on PC Cl3 cell proliferation. It was found that Ang II: (1) induced the phosphorylation of protein kinase $\mathrm{B}(\mathrm{PKB}),(2)$ induced the growth-related early gene c-fos expression, (3) enhanced the cyclin E and $\mathrm{p} 27^{\mathrm{kip}}$ expression, (4) had no effects on Cdk2, and (5) did not affect the transition from $\mathrm{G} 0 / \mathrm{G} 1$ to $\mathrm{S}$ phase. Inhibition of phosphoinositide-3kinase by LY294002 further increased the effect of Ang II on p27 $7^{\text {kip }}$ induction, whilst PKCs inhibition by GF109203X decreased such effect. The role of PKC- $\zeta$ was recognized by the use of a synthetic myristoylated peptide with sequences based on the endogenous $\mathrm{PKC}-\zeta$
\end{abstract}

pseudosubstrate and by $\mathrm{PKC}-\zeta$ downregulation using the small interfering RNA (siRNA). Insulin had a replicating effect on PC Cl3 cells, induced the phosphorylation of PKB, decreased $\mathrm{p} 27^{\mathrm{kip}}$ expression and had no effect on the PKC- $\zeta$ cytosol-to-membrane translocation. $\mathrm{PC} \mathrm{Cl3}$ cell proliferation was induced more potently by simultaneous stimulation with insulin and Ang II than by stimulation with insulin alone, and the effect on $\mathrm{p} 27^{\mathrm{kip}}$ expression was similar to that obtained with insulin only. These observations demonstrate that in PC Cl3 cells Ang II causes a block in G1 phase, although both ERK and PKB pathways are activated, and this effect may be due to the upregulation of $\mathrm{p} 27^{\mathrm{kip}}$ and PKC- $\zeta$ operativity.

Journal of Endocrinology (2006) 191, 727-735

\section{Introduction}

Angiotensin II (Ang II) was originally discovered as a potent vasoconstrictor; however, research in the past several decades has provided ample evidence that Ang II modulates cell growth (Gill \& Simonian 1977, Geisterfer et al. 1988, Naftilan et al. 1989, Bunkenburg et al. 1992). Depending on the specific cell type and presence of other growth factors, Ang II induces proliferation, hypertrophy, apoptosis or differentiation.

The Ang II receptor AT1, is expressed by rat thyroid (Montiel \& Jimenez 1998) and a relationship between thyroid function and several components of the renin-angiotensin system has been established (Montiel et al. 1984, Ruiz et al. 1987, Catanzaro 1995). Recently, our laboratory has shown that $\mathrm{PC} \mathrm{Cl3} \mathrm{cells,} \mathrm{a} \mathrm{rat} \mathrm{thyroid} \mathrm{cell} \mathrm{line,} \mathrm{express} \mathrm{a} \mathrm{functional}$ AT1 receptor that regulates the $\mathrm{Na}^{+} / \mathrm{K}^{+}$ATPase activity and activates the extracellular signal-regulated kinases 1 and 2 (ERK1/2) pathway through the activity of the atypical protein kinase $\mathrm{C}-\zeta$ (Marsigliante $e t$ al. 2003). A direct role of ERK1/2 has been demonstrated in Ang II-induced DNA synthesis and proliferation of cultured rat aortic smooth muscle cells (Marrero et al. 1997).

Since both the activity of the $\mathrm{Na}^{+} / \mathrm{K}^{+}$ATPase and the activation of the ERK pathway are greatly involved in the proliferation of various cells (Ferrandi et al. 2004, Muscella et al. 2004), the purpose of this study was to investigate first whether Ang II affects PC $\mathrm{Cl} 3$ cell proliferation. To this end, we analyzed the effects of Ang II on the transition from G0/G1 to $S$ phase, on cell number and metabolic activity and, finally, on total cell protein content.

Clearly, Ang II induced proliferation that requires complete cell progression through the various steps of the cell cycle. In contrast, cells undergoing Ang II-mediated hypertrophy, apoptosis, and differentiation are arrested in the G1 phase (Wolf \& Wenzel 2003).

The proliferation of mammalian cells is controlled by an intricate network of biochemical pathways that ensure that each cell-cycle event is performed correctly and in the proper sequence. Growth factor-induced signals are required for progression through the G1 phase and must converge, in late G1, on the cell-cycle engine to ensure the commitment of cells to enter S phase (Pardee 1989). The regulation of G1 progression and G1/S transition is governed, at least in part, by the concerted action of cyclin-dependent kinases (Cdks) and their regulatory cyclin subunits (Draetta 1994, Sherr 1994, Grana \& Reddy 1995). Biochemical and genetic data indicate that cyclin E-Cdk2 activity is essential for entry into S phase (Ohtsubo et al. 1995, Krude et al. 1997). The activity of Cdks is regulated by a combination of 
mechanisms. These include the synthesis of cyclin and Cdk, the assembly of these proteins into complexes and the interaction with Cdk inhibitory proteins (Morgan 1995). The Cdk2 inhibitor $\mathrm{p} 27^{\mathrm{kip}}$ has been shown to play an important role in cell-cycle regulation. High levels of $\mathrm{p} 27^{\mathrm{kip}}$, present in quiescent cells, have been shown to decline upon mitogen induction (Sherr \& Roberts 1995). This decrease in $\mathrm{p} 27^{\mathrm{kip}}$ appears to be critical in enabling the cells to enter the cell cycle.

Another important step in response to proliferative signal is the transient transcriptional activation of immediate early genes associated with cell division, such as the protooncogenes c-fos, c-jun, and egr-1 (Herschman 1991). The protein products of these genes are involved in transcriptional control and lead to a cascade of gene activation mediating the growth response. Indeed, it has been shown that Ang II also increases the expression of several growth related genes in vitro, including c-fos (Taubman et al. 1989, Naftilan et al. 1990, Rosenberg \& Hostetter 1993). Ang II has been shown to activate phosphatidylinositol 3-kinases (PI3K) in various cell types (Saward \& Zahradka 1997, Dugourd et al. 2003). PI3K are lipid kinases that phosphorylate the $3^{\prime}-\mathrm{OH}$ group of the inositol ring in inositol phospholipids after activation by a variety of extracellular stimuli. Several downstream targets of PI3K have been identified, such as the serine/threonine kinase Akt, also known as protein kinase B (PKB). Once phosphorylated, Akt activates various proteins involved in many cellular responses, including cell survival and growth promotion (Datta et al. 1999, De Vita et al. 2000). Recently, it has been shown that Akt is phosphorylated and activated by the AT1 receptor in a PI3K-dependent manner in various cell types (Eguchi et al. 1999, Takahashi et al. 1999, Yang \& Raizada 1999, Garcia-Caballero et al. 2001, Rolz et al. 2002).

The major task of the present study was to investigate the mechanisms underlying the proliferative response of PC $\mathrm{Cl} 3$ cells to Ang II. To this end we examined the effects of Ang II on p27 $7^{\mathrm{kip}}$ and other cell-cycle proteins, on $\mathrm{c}$-fos expression and Akt/PKB activity in $\mathrm{PC} \mathrm{Cl3}$ cells.

\section{Materials and Methods}

\section{Materials}

Fetal bovine serum (FBS) and glutamine were from Euroclone (Paignton, UK). Hydrocortisone, transferrin, Lglycyl-histidyl-lysine, and somatostatin were from MP Biomedicals (Irvine, CA, USA). Coon's modified Ham's F12 medium, bovine serum albumin (BSA), and other reagents were from Sigma-Aldrich Co. The mitogenactivated extracellular kinase (MEK) inhibitor PD98059, the protein kinase C (PKC) inhibitor GF109203X, and the PI3K inhibitor LY294002 were obtained from Sigma Chemical Co. Myristoylated PKC- $\zeta$ pseudosubstrate peptide (Myr-

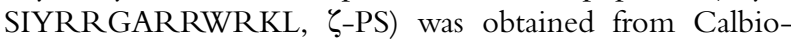
chem-Novabiochem (Schwalbach, Germany).

\section{Cell culture}

Several different batches of the PC $\mathrm{Cl} 3$ cells were used in the experiments and the cells were grown for 40 passages approximately. Each experiment was performed on four different cell preparations, with at least three replicates in a single experiment. PC Cl3 rat thyroid cells were grown in Coon's modified Ham's F12 medium, supplemented with 5\% FBS, containing L-glutamine $(2 \mathrm{mM})$, gentamicin $(50 \mathrm{mg} / \mathrm{ml})$ and six-hormone mixture consisting of insulin $(1 \mu \mathrm{g} / \mathrm{ml})$, hydrocortisone $(3.62 \mu \mathrm{g} / \mathrm{ml})$, transferrin $(5 \mu \mathrm{g} / \mathrm{ml})$, L-glycylhistidyl-lysine $(20 \mathrm{ng} / \mathrm{ml})$, somatostatin $(10 \mathrm{ng} / \mathrm{ml})$, and thyroid-stimulating hormone (TSH; $1 \mathrm{mU} / \mathrm{ml})$. The cells were maintained in a water-saturated atmosphere of $5 \% \mathrm{CO}_{2}$ and $95 \%$ air at $37{ }^{\circ} \mathrm{C}$. The cells were passaged every $7-8$ days, and the culture medium was changed every $2-3$ days.

\section{Cell proliferation assay}

The conversion of MTT (3-(4,5-dimethylthiazol-2-yl)-2,5diphenol tetrazolium bromide) by $\mathrm{PC} \mathrm{Cl3}$ cells was used as an indicator of cell number as described by Mosmann (1983), with some modification as described previously (Muscella et al. 2002). This method measures the reduction of MTT by active mitochondria, which results in a colorimetric change measured at optical density $570 . \mathrm{PC} \mathrm{Cl} 3$ cells were grown in 96-well plates for 1 day in Coon's modified Ham's F12 medium, supplemented with $5 \%$ FBS, containing a mixture of six hormones. The media were replaced with hormone-free media, supplemented with $0.5 \%$ FBS ('starved cells'), for $48 \mathrm{~h}$ to induce quiescence. Ang II(100 nM) or insulin (100nM) or Ang II and insulin in combination (used in a single dose of $100 \mathrm{nM}$ ) were added to each well, except for one strip, used as control. After 24, 48, and $72 \mathrm{~h}$, MTT $(250 \mu \mathrm{g} / \mathrm{ml})$ was added to the cells for a 4-h incubation and cells were lysed in acidified isopropanol. The plates were subsequently read on a spectrophotometer at $570 \mathrm{~nm}$ (Bio-Rad). The results were expressed as percent viability of each well in respect of control.

\section{Cell count}

PC Cl3 cells were seeded at $5 \times 10^{4}$ cells/well on 24 -well plates, and cells were counted in a Thomas cell-chamber 24 , 48 and $72 \mathrm{~h}$ after treatment as described above.

\section{Cell-cycle analysis}

Cell cycle was evaluated by staining cellular DNA with the DNA intercalator propidium iodide (PI) using a semiautomatic procedure (DNA-Prep Reagents Kit; Beckman Coulter Inc., Fullerton, CA, USA), followed by analysis on an EPICS XL flow cytometer.

In brief, $1 \times 10^{6}$ cells, starved for $48 \mathrm{~h}$ in fresh medium without hormones and with $0 \cdot 5 \% \mathrm{FBS}$, and then stimulated with agonists for $18 \mathrm{~h}$. Then cells were harvested by trypsinization, pelletted, washed twice with free calcium 
and magnesium PBS, fixed, permeabilized and stained by addition of $100 \mu \mathrm{l}$ detergent reagent lysing and permeabilizing reagent (LPR), followed by $1 \mathrm{ml}$ PI solution. After mixing, samples were incubated for $30 \mathrm{~min}$ at room temperature and analyzed by flow cytometry. Cell-cycle data analysis was performed on 20000 events.

\section{Western blot analysis}

To obtain whole protein cell extracts for western blot analysis of Akt/PKB, c-fos, cyclin E, Cdk2, and p2 $7^{\text {kip }} \mathrm{PC} \mathrm{Cl3} \mathrm{cells}$ were scraped in the following buffer A $(\mathrm{mM}): 20$ Tris $-\mathrm{HCl}$, $\mathrm{pH} 8$, containing $100 \mathrm{NaCl}, 2$ EDTA, $2 \mathrm{~N}_{3} \mathrm{VO}_{4}, 2 \%$ Nonidet $\mathrm{P}-40$, and also containing a mixture of protease inhibitors, including 0.5 phenylmethylsulfonyl fluoride, $10 \mu \mathrm{g} / \mathrm{ml}$ leupeptin, and $10 \mu \mathrm{g} / \mathrm{ml}$ pepstatin. Cells were then passed several times through a 20 -gauge syringe and centrifuged at $16000 \mathrm{~g}$ for $20 \mathrm{~min}$ at $4{ }^{\circ} \mathrm{C}$. Proteins were determined with the Bio-Rad protein assay kit 1, using lyophilized BSA as standard.

For the separation of $\mathrm{PKC}-\zeta$ between the cytosol and membrane, after washing with cold PBS, PC Cl3 cells were scraped into the following buffer $(\mathrm{mM})$ : 20 Tris- $\mathrm{HCl}, \mathrm{pH}$ $7 \cdot 5$, containing 250 sucrose, 2 EGTA, 2 EDTA, $10 \mathrm{MgCl}_{2}, 2$ dithiothreitol, and protease inhibitors, and after two freeze and thaw cycles, cells were centrifuged at $900 \boldsymbol{g}$ for $15 \mathrm{~min}$ at $4{ }^{\circ} \mathrm{C}$ and the resultant pellet was resuspended and centrifuged once more. The pooled supernatants were centrifuged at $100000 \boldsymbol{g}$ for $60 \mathrm{~min}$ to obtain cytosolic and membrane fractions. The pellet at $100000 \mathrm{~g}$ was solubilized in buffer $\mathrm{B}(\mathrm{mM})$ : 20 Tris- $\mathrm{HCl}, \mathrm{pH} 7.5,150 \mathrm{NaCl}, 1$ EGTA, 1 EDTA, and protease inhibitors, containing 2\% Non idet P-40.

Equal amounts of proteins $(50 \mu \mathrm{g})$ from homogenates were loaded and separated on 10\% SDS gels by electrophoresis and transferred to a nitrocellulose membrane. The sheet was blocked with $3 \%$ non-fat dry milk in buffered saline before incubation for $1 \mathrm{~h}$ at $25{ }^{\circ} \mathrm{C}$ with $2 \mu \mathrm{g} / \mathrm{ml}$ of anti body (Ab) to Akt/PKB (Sc-7985-R), c-fos (Sc-52), cyclin E (Sc-481), Cdk2 (Sc-6248), p27 ${ }^{\mathrm{kip}}$ (Sc-1641) and PKC- $\zeta$ isoform (Sc-876) (all from Santa Cruz Biotechnology, Santa Cruz, CA, USA) in blocking solution. The proteins were detected with goat anti-rabbit or anti-mouse $\operatorname{IgG}$ conjugated with peroxidase (Santa Cruz Biotechnology), using enhanced chemiluminescence (ECL) (Amersham Life Sciences Inc.). The intensity of the bands was quantified by scanning densitometry using the NIH Image 1.62 software (National Institutes of Health, Bethesda, MD, USA).

\section{Total protein content}

$\mathrm{PC} \mathrm{Cl} 3$ cells were plated in six-well plates $\left(1 \times 10^{4}\right.$ cells/well), starved for $48 \mathrm{~h}$, and stimulated with a daily dose of Ang II. Total protein was determined by the method of Lowry et al. (1951) after 24, 48 and $72 \mathrm{~h}$.
Design and preparation of small interfering $R N A$ (siRNA)

siRNAs were prepared by an in vitro transcription method. Initially, four siRNA- $\zeta$ target sites specific to rat PKC- $\zeta$ mRNA, as determined by blast analysis, were chosen. For each siRNA, sense and antisense templates were designed based on each target sequence and partial $\mathrm{T} 7$ promoter sequence. All template oligonucleotides were chemically synthesized and PAGE purified. In vitro transcription, annealing, and purification of siRNA duplexes were performed using the protocol supplied with the T7 RiboMAX Express RNAi System (Promega). Briefly, $2 \mu \mathrm{g}$ approximately of each single-strand (ss) transcription template was first annealed with the $\mathrm{T} 7$ promoter and filled in by Klenow DNA polymerase to form double-strand transcription templates. For preparation of each siRNA duplex, transcription reactions were first performed with separated antisense and sense templates using the T7 RNA polymerase provided with the kit, and then annealed to form siRNA duplexes. Then, the siRNA duplex was treated with DNase and RNase to remove the extranucleotides of transcribed siRNA to meet the structural 3VUU overhang and $5^{\prime}$ phosphate requirement.

PKC- $\zeta$ immunoblotting was performed $24 \mathrm{~h}$ posttransfection to determine the efficiency of siRNA Incorporation in $\mathrm{PC} \mathrm{Cl} 3$ and to measure $\mathrm{PKC}-\zeta$ expression. Quantitative analysis of $\mathrm{PKC}-\zeta$ expression, as measured by intensity of PKC- $\zeta$ immunoreactivity, in siRNA- $\zeta$ - or siRNA-NS-transfected $\mathrm{PC} \mathrm{Cl} 3$ revealed a higher reduction in $\mathrm{PKC}-\zeta$ expression with the following sense RNA sequence: 5'GCUGAGAUCUGUAUCGCUC-3'.

\section{siRNA transfection}

PC Cl3 cells (50-70\% confluence) were transfected with siRNA duplexes using the protocol supplied with the CodeBreaker siRNA transfection reagent (Promega). Briefly, transfection reagent was first diluted into Coon's modified Ham's F12 medium without serum and antibiotics for about $15 \mathrm{~min}$, and then the siRNA duplex was added to the medium to form a lipid-siRNA complex. Following an additional 15-min incubation, transfection was initiated by adding the lipid-siRNA complex to six-well plates. The final concentration of siRNA was $30 \mathrm{nM}$.

\section{Statistical analysis}

Experimental points represent the mean \pm s.D. of $4-6$ replicates. Statistical analysis was carried out using Student's $t$-test for unpaired samples and ANOVA. When indicated, post hoc tests (Bonferroni and Dunn) were also performed.

A $P$ value of $<0.05$ was considered to be statistically significant. 
A

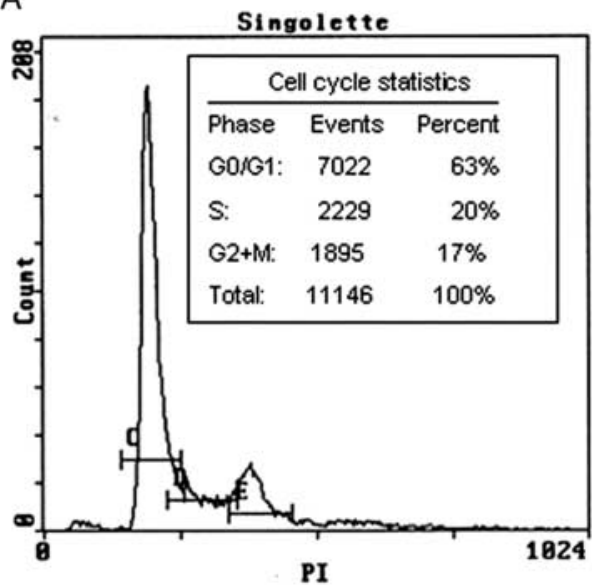

C

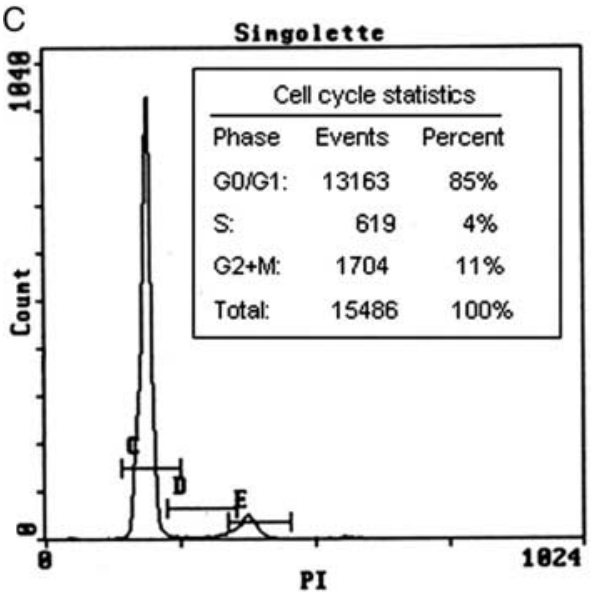

B

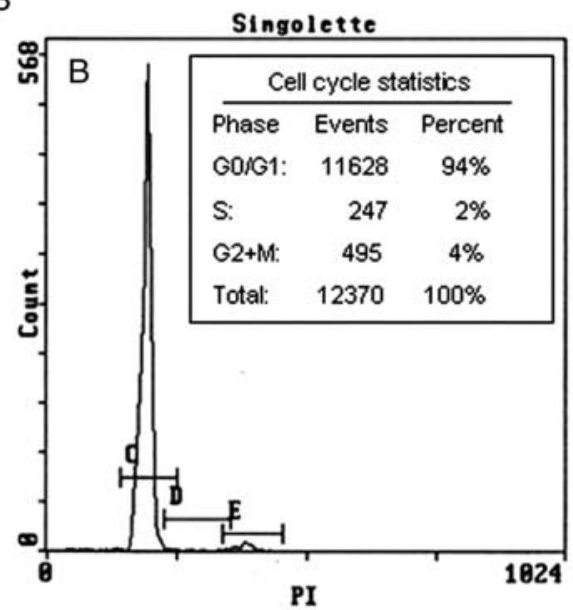

D

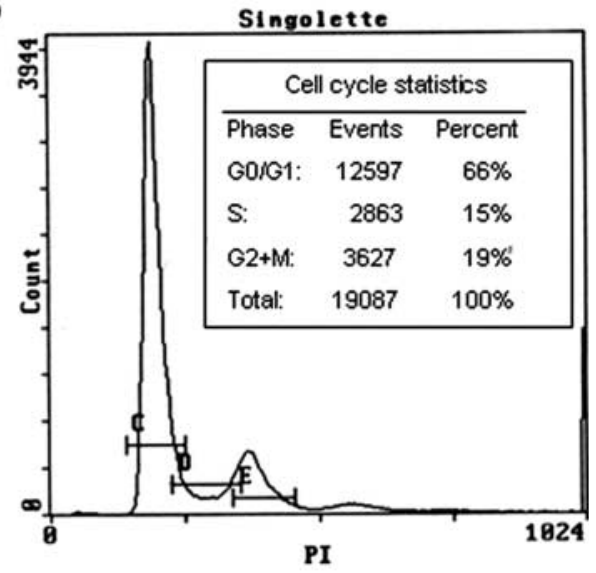

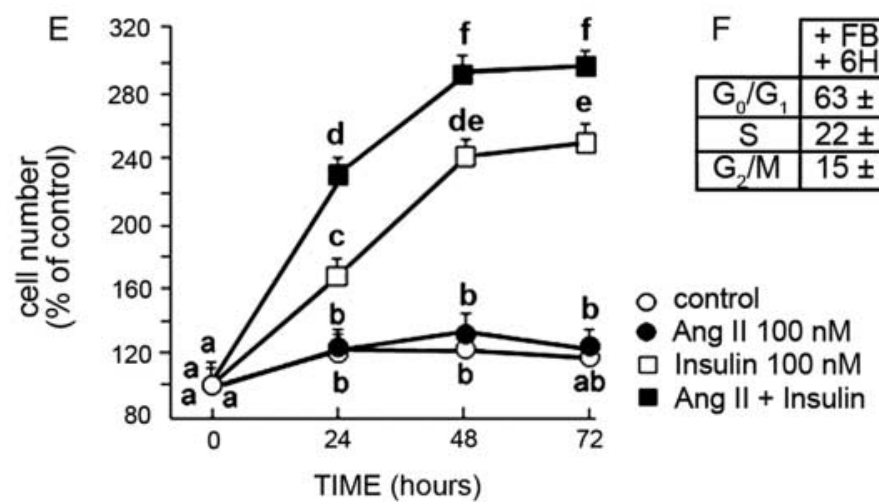

Figure 1 Proliferative effects of Ang II and insulin in PC Cl3 cells. The histograms show cell cycle analysis of PC Cl3 cells grown in complete culture medium (containing FBS and 6 hormones growth factor mixture) (A), starved for $48 \mathrm{~h}$ (G0/G1 syncronization) (B), starved for $48 \mathrm{~h}$ and then treated for $18 \mathrm{~h}$ with Ang II $100 \mathrm{nM}$ (C) and insulin $100 \mathrm{nM}$ as positive control (D). The table shows the mean \pm s.D. of the percentage distribution of the cells in the different phases of the cell cycle, obtained in other independent experiments $(n=4)$ performed on different cell preparations. Statistical analysis was carried out using Student's $t$-test for unpaired samples: $P<0 \cdot 01$ between starved and insulin-treated $\mathrm{PC} \mathrm{Cl} 3$ cells; $P>0 \cdot 05$ between starved and Ang II-treated PC Cl3 cells; $P<0 \cdot 01$ between Ang II and insulin-treated $\mathrm{PC} \mathrm{Cl} 3$ cells (E). The effect of insulin and Ang II on cell proliferation is additive. Starved PC Cl3 cells were treated without or with Ang II or Insulin or incubated with insulin and Ang II in combination agonists for the indicated time. Proliferation was analyzed by a spectrophotometric MTT assay as described in Materials and Methods. The data are mean \pm S.D. of four different experiments run in eight replicates and are presented as percent proliferation of control. ANOVA: $P<0 \cdot 0001$. Values with shared letters are not significantly different according to Bonferroni/Dunn post hoc tests. 


\section{Results}

\section{Effect of Ang II on PC Cl3 cell proliferation}

Proliferation was analyzed by a spectrophotometric 3-(4,5dimethylthiazol-2-yl)-2,5-diphenol-2H-tetrazolium bromide (MTT) assay and confirmed by direct cell counts. The basal metabolic activity was unchanged in the presence of Ang II and Ang II had no replicating effect on starved PC Cl3 cells (Fig. 1E). The same results were obtained by direct cell counting (data not shown). As a positive control for the proliferation studies insulin was used, which is known to be a powerful mitogen for $\mathrm{PC} \mathrm{Cl3}$ cells and to stimulate the phosphorylation of ERK1/2 (Florio et al. 2001). Indeed, insulin produced mitogenic effects in $\mathrm{PC} \mathrm{Cl3}$ cells (Fig. 1D and E). PC Cl3 cell proliferation was induced more potently by simultaneous stimulation with insulin (100 nM) and Ang II (100 nM) than by stimulation with insulin alone (Fig. 1E). The growth characteristics of PC Cl3 cell line has been studied by means of flow cytometry analysis. The histograms depict the cell-cycle distribution of $\mathrm{PC} \mathrm{Cl} 3$ cells grown in medium supplemented with FBS and six hormones mixture (Fig. 1A) and after $48 \mathrm{~h}$ starvation (Fig. 1B). More than $90 \%$ of PC Cl3 cells appeared blocked in G0/G1 phases and Ang II (100 nM) was not able to increase the G1/S progression in the cell cycle (Fig. 1C).

Ang II (100 nM) did not increase the protein/cell number ratio (control cells $=188 \cdot 5 \pm 7 \cdot 4 \mathrm{pg} /$ cell; cells treated with $100 \mathrm{nM}$ Ang II $=191 \pm 8 \cdot 7 \mathrm{pg} /$ cell), indicating that Ang II did not cause hypertrophy as in other cell types.

\section{Effects of Ang II on cyclin E, Cdk2 and p27 $7^{k i p}$ expressions}

Cyclin E, Cdk 2 but not $\mathrm{p} 27^{\mathrm{kip}}$ were expressed in starved PC Cl3 cells. Treatment with $100 \mathrm{nM}$ Ang II caused a small but significant increase in cyclin $\mathrm{E}$ expression, which reached a maximum at $20 \mathrm{~h}$ (Fig. 2B), had caused no effect on Cdk2 (Fig. 2C) and a significant increase in p $27^{\mathrm{kip}}$ after 4-h incubation with Ang II, and reaching a maximum at $20 \mathrm{~h}$ (Fig. 2A).

\section{Ang II induces phosphorylation of PKB/Akt}

Since Ang II is known to increase, in some cells, the phosphorylation state of Akt/PKB (Takahashi et al. 1999), we studied the effects of Ang II treatment on PKB/Akt. Stimulation of $\mathrm{PC} \mathrm{Cl} 3$ cells with Ang II increased the phosphorylation state of $\mathrm{PKB} / \mathrm{Akt}$ in a time and concentration dependent manner. Ang II caused the phosphorylation of Akt/ $\mathrm{PKB}$ within $3 \mathrm{~min}$, reached a maximum at $1 \mathrm{~h}$ and remained unchanged for up to $24 \mathrm{~h}$ (Fig. 3A). The maximum effect was achieved at $100 \mathrm{nM}$ of Ang II (Fig. 3B).

\section{Role of PI3K and MEK on $p 27^{\text {kip }}$ induction}

Since the ERK $1 / 2$ and PI3K pathways are independently activated, and implicated in Ang II-mediated DNA synthesis and cell number increase in various cells (Dugourd et al. 2003), we further examined the effect of the PI3K inhibitor LY294002 and of the MEK inhibitor PD98059 on Ang II-induced p27 $7^{\text {kip }}$ activation. Pre-treatment of PC Cl3 cells with 1-100 $\mu \mathrm{M}$ LY294002 enhanced the Ang II-stimulated phosphorylation of p27 kip (Fig. 4), while pre-treatment of PC Cl3 cells with 1$25 \mu \mathrm{M}$ PD98059 did not have any significant effect on the Ang II-stimulated phosphorylation of $\mathrm{p} 27^{\text {kip }}$ (Fig. 4).

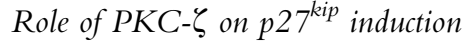

Since, we showed previously that Ang II activates ERK pathway through the activity of atypical $\mathrm{PKC}-\zeta, \mathrm{PC} \mathrm{Cl} 3$ cells were also pre-treated with the PKC inhibitor GF109203X. As shown in Fig. 4, GF109203X greatly inhibited the induction of $\mathrm{p} 27^{\mathrm{kip}}$ at the highest concentration used; since GF109203X has a half-maximal inhibitory constant $\left(\mathrm{IC}_{50}\right)$ for $\mathrm{PKC}-\zeta$ isozyme $>1.5 \mu \mathrm{M}$ (whereas of $110 \mathrm{nM}$ or lower for all the other PKC isoforms (Martiny-Baron et al. 1993), which are not activated by Ang II in these cells) these results suggest that a atypical PKC isoform is involved in the induction of $\mathrm{p} 27^{\mathrm{kip}}$ by Ang II.

PC Cl3 cells were also pre-incubated with 10, 50, and $100 \mu \mathrm{M}$ cell permeable $\zeta$-PS for $60 \mathrm{~min}$. $\zeta$-PS did not affect the basal $\mathrm{p} 27^{\mathrm{kip}}$ but provoked a dose-dependent inhibition of Ang II-induced p $27^{\text {kip }}$ activation (Fig. 5A).

We next examined the effect of the downregulation of $\mathrm{PKC}-\zeta$ isoform by siRNA, on $\mathrm{p} 27^{\mathrm{kip}}$ induction. Preliminary experiments by western blotting using antibodies against PKC- $\zeta$, demonstrated the efficient downregulation induced by siRNA (Fig. 5B). Densitometric analysis revealed a $76 \%$ reduction in endogenous $\mathrm{PKC}-\zeta$ protein expression following transfection with $30 \mathrm{nM}$ siRNA- $\zeta$ for $24 \mathrm{~h}$ (Fig. 5C).

The siRNA inhibition of $\mathrm{PKC}-\zeta$ prevent the Ang II-mediated increase of $\mathrm{p} 27^{\mathrm{kip}}$ (Fig. 5B).

These results confirmed that atypical $\mathrm{PKC}-\zeta$ is involved in the induction of $\mathrm{p} 27^{\mathrm{kip}}$ by Ang II.

\section{Ang II induces c-fos expression in PC Cl3}

Western blot analysis using an antibody that recognized the c-fos protein showed that in quiescent PC Cl3 cells Ang II stimulates the expression of this protein in a dose-dependent way (1-1000 nM; Fig. 6). The expression of c-fos protooncogene protein peaked at $30 \mathrm{~min}$. On the basis of these results further experiments were carried out using 30-min incubation time for protein detection.

\section{The effects of insulin on PKC- $\zeta, E R K 1 / 2, P K B$, and $p 27^{k i p}$ in PC Cl3 cells}

As reported above (Fig. 1A), insulin has a replicating effect on PC Cl3 cells. Noteworthy, the proliferation of PC $\mathrm{Cl} 3$ cells incubated with insulin and Ang II in combination (used in a single dose of $100 \mathrm{nM}$ ) appeared further increased. We therefore studied the effects of $100 \mathrm{nM}$ insulin on the same 
A
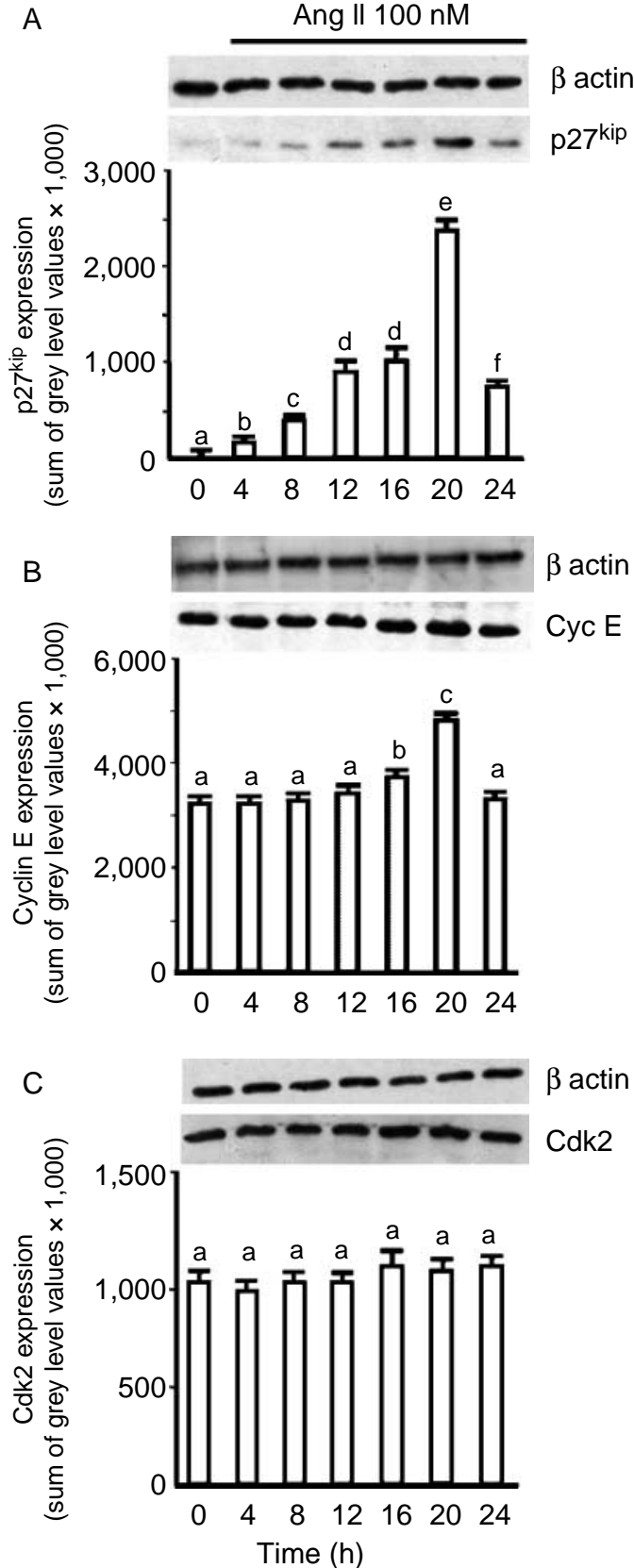

Figure 2 Effects of Ang II on the expression level of (A) p2 $7^{\text {kip }}$ (B) cyclin E and (C) Cdk2 in $\mathrm{PC} \mathrm{Cl} 3$ cells. Starved PC Cl3 cells were stimulated with $100 \mathrm{nM}$ Ang II for different times over a $24 \mathrm{~h}$ period. Equal amounts of lysate protein were resolved by SDS-gel electrophoresis on $10 \%$ acrylamide gel and transferred to polyvinylidine difluoride (PVDF) membrane. The membrane was probed with anti-p2 $7^{\mathrm{kip}}$, anti-cyclin E and anti-Cdk2 antibodies and the proteins visualized by chemiluminescence detection. To confirm equal protein loading in western blot, the membranes were reprobed with $\beta$-actin antibody. Densitometry analysis of bands obtained in other independent experiments $(n=4)$ performed on different cell preparations are represented as histograms. Values with shared letters are not significantly different according to Bonferroni/Dunn post hoc tests. CycE, cyclin E.

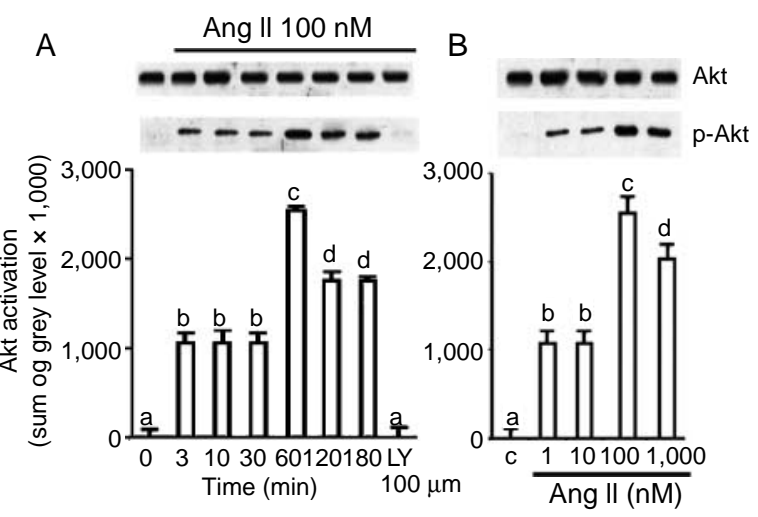

Figure 3 The Ang II-induced phosphorylation of Akt in $\mathrm{PC} \mathrm{Cl} 3$ cells. (A) Starved PC Cl3 cells were treated without or with $100 \mathrm{nM}$ Ang II for the indicated periods. (B) Starved cells were incubated with increasing concentration of Ang II for $60 \mathrm{~min}$. The cell extracts were electrophoretised through $10 \%$ SDS-PAGE gel and analyzed by western blotting using anti-phospho-Akt (p-Akt) antibody, and after stripping with anti-total (phosphorylated plus unphosphorylated) Akt (Akt) antibody. Representative immunoblots are shown. Densitometry analysis of bands obtained in other independent experiments $(n=4)$ performed on different cell preparations, are represented as histograms. Values with shared letters are not significantly different according to Bonferroni/Dunn post hoc tests.

proteins, which are targets of the Ang II action. As shown in Fig. 7 PC Cl3 cells incubated with $100 \mathrm{nM}$ insulin showed a significant decrease of $\mathrm{p} 27^{\mathrm{kip}}$, a small but significant increase in cyclin E expression, no effects on Cdk2 (Fig. 7A) and the

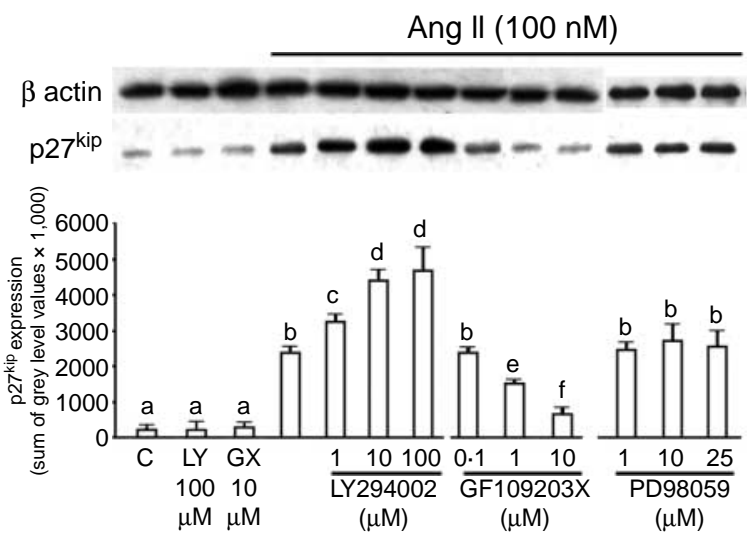

Figure 4 Role of PI3K, ERK1/2 and PKC- $\zeta$ on the effects of Ang II on p2 $7^{\text {kip }}$ protein. Starved PC Cl3 cells were pre-treated for $45 \mathrm{~min}$ with LY294002 (LY), PD98059 and GF109203X (GX) and then stimulated with $100 \mathrm{nM}$ Ang II for $20 \mathrm{~h}$. Cells were also treated for 45 min with $100 \mu \mathrm{M}$ LY294002 and $10 \mu \mathrm{M}$ GF109203X only. The resolved proteins were immunoblotted with anti-p2 $7^{\mathrm{kip}}$ and the proteins visualized by chemiluminescence detection. To confirm equal protein loading in western blot, the membranes were reprobed with $\beta$-actin antibody. Densitometry analysis of bands obtained in other independent experiments $(n=4)$ performed on different cell preparations, are represented as histograms. Values with shared letters are not significantly different according to Bonferroni/Dunn post hoc tests. 


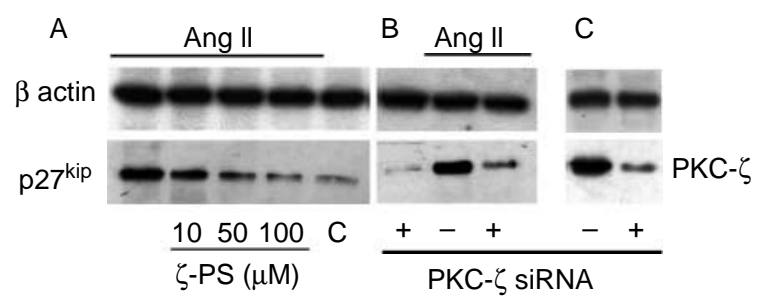

Figure 5 Role of $\mathrm{PKC}-\zeta$ on p2 $7^{\mathrm{kip}}$ induction. (A) Starved $\mathrm{PC} \mathrm{Cl} 3$ cells were pre-treated with increasing concentrations of a synthetic myristoylated pseudosubstrate of PKC- $\zeta$ ( $\zeta-P S)$ for $60 \mathrm{~min}$ and then stimulated with $100 \mathrm{nM}$ Ang II for $20 \mathrm{~h}$. (B) Cells were also transfected with siRNA- $\zeta$ and then stimulated without or with $100 \mathrm{nM}$ Ang II for $20 \mathrm{~h}$. The resolved proteins were immunoblotted with anti-p2 $7^{\mathrm{kip}}$ and the proteins visualized by chemiluminescence detection. (C) Analysis of PKC- $\zeta$ expression in siRNA- $\zeta$ transfected or not PC Cl3 cells. To confirm equal protein loading in western blot, the membranes were reprobed with $\beta$-actin antibody. The figure is representative of three independent experiments. C, control.

phosphorylation of PKB (Fig. 7B); finally, insulin did not provoke translocation of PKC- $\zeta$ from the cytosol to cellular membranes (Fig. 7D). Interestingly, the effect of the simultaneous stimulation with insulin and Ang II on $\mathrm{p} 27^{\mathrm{kip}}$ expression (Fig. 7C) and on $\mathrm{PKC}-\zeta$ translocation (Fig. 7D) was similar to the effect obtained with insulin alone.

\section{Discussion}

In the present study, we have investigated the growthpromoting effects of Angiotensin II (Ang II) in PC Cl3 cells since, as previously shown (Marsigliante et al. 2003), Ang II stimulates the phosphorylation of the extracellular signal-

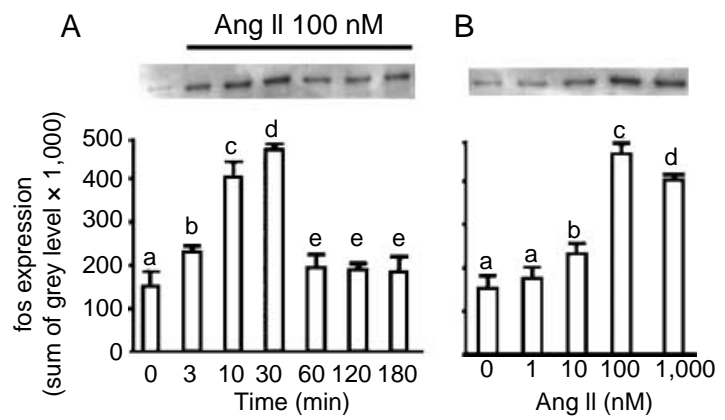

Figure 6 The Ang II-induced expression of $\mathrm{c}$-fos protein in PC $\mathrm{Cl} 3$ cells. (A) Starved $\mathrm{PC} \mathrm{Cl} 3$ cells were treated without or with $100 \mathrm{nM}$ Ang II for the indicated periods. (B) Cells were incubated with increasing concentration of Ang II for 30 min in serum-starved medium. The cell extracts were electrophoretised through 10\% SDS-PAGE gel and analyzed by western blotting using anti-c-fos. The same results were obtained in other independent experiments $(n=4)$ performed on different cell preparations. Representative immunoblots are shown. Values with shared letters are not significantly different according to Bonferroni/Dunn post hoc tests. regulated kinases 1 and 2 (ERK1 and 2). ERKs are involved in the activation of nuclear transcription factors, such as the c-fos, c-jun, and c-myc protooncogenes (Wagstaff et al. 2000, Buckley et al. 2001, Ekokoski et al. 2001). c-fos and c-jun proteins associate to form homo- and hetero-dimer AP-1 complexes that bind to specific DNA sequences of target genes. The regulatory region of the $c$-fos gene contains several cis-acting elements, which are the target of a variety of interdependent signal transduction pathways, such as PKA, PKC, calmodulin (CAM) kinase, and mitogen activated protein (MAP) kinase cascades. c-fos is induced by all studied (co)mitogenic stimuli, including TSH (cAMP), insulin/ insulin-like growth factor-I, phorbol esters, serum and growth factors in FRTL-5 (Colletta et al. 1986, Isozaki \& Kohn 1987), and Wistar rat thyroid (WRT) cells (Tominaga et al. 1994), and in $\operatorname{dog}$ (Deleu et al. 1999) and human thyrocytes (Huber et al. 1991, Heinrich \& Kraiem 1997). c-fos expression has been claimed to be required for TSHdependent proliferation of Fisher rat thyroid low serum

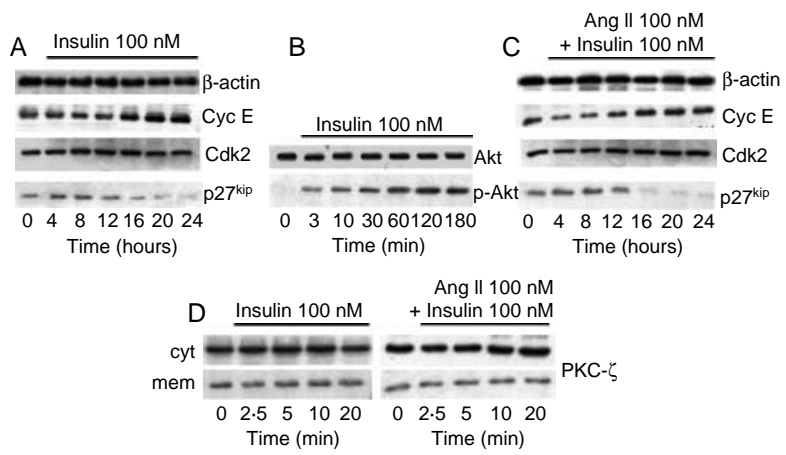

Figure 7 Effects of insulin on (A) the expression level of p27 $7^{\text {kip }}$, cyclin E (Cyc E) and Cdk2, (B) the phosphorylation state of Akt, (D) the PKC- $\zeta$ translocation from cytosol (cyt) to membrane (mem) in PC $\mathrm{Cl} 3$ cells. (C) Effects of the simultaneous stimulation with insulin and Ang II on expression level of p2 $7^{\mathrm{kip}}$, cyclin E and Cdk2. (A and B) Starved PC Cl3 cells were stimulated with $100 \mathrm{nM}$ insulin for the indicated periods. Equal amounts of lysate protein were resolved by SDS-gel electrophoresis on $10 \%$ acrylamide gel and transferred to PVDF membrane. The membranes were probed with $(\mathrm{A})$ antip2 $7^{\text {kip }}$, anti-cyclin E, anti-Cdk2 or (B) anti-phospho-Akt (p-Akt), and after stripping with anti-total (phosphorylated plus unphosphorylated) Akt (Akt) antibodies and the proteins visualized by chemiluminescence detection. To confirm equal protein loading in western blot, the membranes were reprobed with $\beta$-actin antibody. (C) Starved PC Cl3 cells were incubated with insulin and Ang II in combination (used in a single dose of $100 \mathrm{nM}$ ) and equal amounts of lysate protein were resolved by SDS-gel electrophoresis on $10 \%$ acrylamide gel and transferred to PVDF membrane. The membranes were probed with anti-p27 ${ }^{\mathrm{kip}}$, anti-cyclin E and anti-Cdk2 antibodies. To confirm equal protein loading in western blot, the membranes were reprobed with $\beta$-actin antibody. (D) Starved PC $\mathrm{Cl} 3$ cells were treated with insulin $(100 \mathrm{nM})$ or with insulin (100 nM) in combination with Ang II (100 nM) for the indicated periods and cytosol (cyt) and membrane (mem) fractions were used for immunoblotting with PKC- $\zeta$ specific antibody. Each figure is representative of four independent experiments performed on different cell preparations. 
(FRTL)-5 cells (Foti et al. 1990), and the activation of AT1 receptors has been shown to induce, in other cell systems, the expression of c-fos (Muscella et al. 2002).

The results of the present study showed that Ang II activated ERK signal transduction pathway and induced c-fos expression without acting as a mitogen in $\mathrm{PC} \mathrm{Cl3}$ cells. Since, in some cell types, such as vascular smooth muscle cells, the Ang II-induced proliferation appeared mediated by the stimulation of ERK1/2 cascade (Marrero et al. 1997) together with the activation of PI3K (Saward \& Zahradka 1997), we consequently investigated the Ang II-induced Akt activation also in PC Cl3 cells. The results demonstrated that Ang II induced Ser-437 phosphorylation of Akt, an activation that is not sufficient for proliferation of $\mathrm{PC} \mathrm{Cl} 3$ cells. However, although both ERK and PI3K/Akt pathways are activated, the effects Ang II in PC Cl3 proliferation are not evident. Since progression through the cell cycle is controlled by a series of cyclin and Cdk complexes that may be inactivated by Cdk inhibitors, to further determine the role of Ang II in PC $\mathrm{Cl} 3$ cells, we studied the expression of cyclin $\mathrm{E}, \mathrm{Cdk}_{2}$ and the Cdk-inhibitor $\mathrm{p} 27^{\mathrm{kip}}$ in $\mathrm{PC} \mathrm{Cl3}$ cells stimulated with Ang II. Compared with the cells grown in serum-free medium, Ang II treatment enhanced the expression of $\mathrm{p} 27^{\mathrm{kip}}$ protein; this may cause a block in the G1 phase of Ang II-stimulated PC $\mathrm{Cl} 3$ cells, which are not able to progress into the $\mathrm{S}$ phase. It is interesting to speculate that G1 phase entry coupled with subsequent cell-cycle arrest may be a general mechanism for cellular hypertrophy. Nevertheless, Ang II did not increase the protein/cell number ratio indicating that it did not cause hypertrophy as in other cell types.

Thus these observations prompted us to further investigate the relationship between PI3K, ERK1/2 and p $27^{\mathrm{kip}}$. We took advantage of the well-characterized PI3K inhibitor LY294002 and of the MEK inhibitor PD98059. We found that LY294002 increases $\mathrm{p} 27^{\mathrm{kip}}$ induction via Ang II, while PD98059 had no effects (Fig. 4). This may be due to the fact that inhibition of the PI3K/Akt pathway resulted in loss of $\mathrm{p} 27^{\mathrm{kip}}$ from cyclin D1 complexes, a shift of $\mathrm{p} 27^{\mathrm{kip}}$ to cyclin E-Cdk2 both of which precede G1 arrest (Liang et al. 2002). Since insulin is able to stimulate the proliferation of $\mathrm{PC} \mathrm{Cl3}$ cells and activates the same pathways that are activated by Ang II, other than the cytosol-to-membrane translocation of $\mathrm{PKC}-\zeta$, we examined the effects of the inhibition of this upstream activator of ERK1/2. We found that GF109203X greatly inhibited $\mathrm{p} 27^{\mathrm{kip}}$ induction via Ang II, suggesting that $\mathrm{PKC}-\zeta$ may reduce $\mathrm{p} 27^{\mathrm{kip}}$ ubiquination and degradation.

Furthermore, the role of $\mathrm{PKC}-\zeta$ was proved by the use of its pseudosubstrate that efficiently inhibited the Ang II response on $\mathrm{p} 27^{\mathrm{kip}}$ induction and also by $\mathrm{PKC}-\zeta$ downregulation using the siRNA (Fig. 5).

However, the exact signal transduction pathways by which Ang II causes cell-cycle arrest are unknown, while it is clear that Ang II activates multiple signaling pathways, including $\mathrm{PKC}-\zeta$, MAPK and Akt that control cellular growth responses. In tubular cells Ang II leads to phosphorylation of the mitogen-activated protein kinases ERK1/2 that phosphorylate p $27^{\mathrm{kip}}$ at serine residues. The $\mathrm{p} 27^{\mathrm{kip}}$ phosphorylation at serine/theonine residues leads, in contrast to tyrosine phosphorylation, to an increased stability and less degradation through the ubiquitin pathway (Wolf \& Wenzel 2003). Therefore, it is possible that Ang IIstimulated $\mathrm{PKC}-\zeta$ activation has a similar role in the processes that regulate $\mathrm{p} 27^{\mathrm{kip}}$ stability, although we can only speculate at this point. Consistent with the higher proliferative effects of co-stimulation with insulin and Ang II, it would be reasonable to postulate that an additional functional pathway exists by which insulin can modulate the stability of $\mathrm{p} 27^{\mathrm{kip}}$ at least through the inhibition of the Ang II-activated PKC- $\zeta$ pathway.

In summary, the results of the present study provide demonstration that (1) in $\mathrm{PC} \mathrm{Cl} 3$ cells Ang II stimulates proliferation, but at the same time it stimulates growth inhibitory systems causing a block in G1 phase, although both MAPK and PI3K/Akt pathways are active and (2) this effect may be, at least in part, due to the upregulation of $\mathrm{p} 27^{\mathrm{kip}}$ controlled by the activity of $\mathrm{PKC}-\zeta$.

\section{Acknowledgements}

The authors declare that there is no conflict of interest that would prejudice the impartiality of this scientific work.

\section{References}

Buckley KA, WagstaffSC, McKay G, Gaw A, Hipskind RA, Bilbe G, GallagherJA \& Bowler WB 2001 Parathyroid hormone potentiates nucleotide-induced $\left[\mathrm{Ca}^{2+}\right]_{\mathrm{i}}$ release in rat osteoblasts independently of $\mathrm{Gq}$ activation or cyclic monophosphate accumulation. A mechanism for localizing systemic responses in bone. Journal of Biological Chemistry 276 9565-9571.

Bunkenburg B, Van Amelsvoort T, Rogg H \& Wood JM 1992 Receptormediated effects of angiotensin II on growth of vascular smooth muscle cells from spontaneously hypertensive rats. Hypertension 20 746-754.

Catanzaro DF 1995 The molecular biology of renin gene expression. In Hypertension: Pathophysiology, Diagnosis and Management, pp 1589-1605. Eds JH Laragh \& BM Brenner. New York: Raven Press.

Colletta G, Cirafici AM \& Vecchio G 1986 Induction of the c-fos oncogene by thyrotropic hormone in rat thyroid cells in culture. Science 233 458-460.

Datta SR, Brunet A \& Greenberg ME 1999 Cellular survival: a play in three Akts. Genes and Development 13 2905-2927.

Deleu S, Pirson I, Clermont F, Nakamura T, Dumont JE \& Maenhaut C 1999 Immediate early gene expression in dog thyrocytes in response to growth, proliferation, and differentiation stimuli. Journal of Cellular Physiology 181 342-354.

De Vita G, Berlingieri MT, Visconti R, Castellone MD, Viglietto G, Baldassarre G, Zannini A, Bellacosa M, Tsichlis PN, Fusco A et al. 2000 $\mathrm{Akt} /$ protein kinase $\mathrm{B}$ promotes survival and hormone-independent proliferation of thyroid cells in the absence of dedifferentiating and transforming effects. Cancer Research 60 3916-3920.

Draetta GF 1994 Mammalian G1 cyclins. Current Opinion in Cell Biology 6 842-846.

Dugourd C, Gervais M, Corvol P \& Monnot C 2003 Akt is a major downstream target of PI3-kinase involved in angiotensin II-induced proliferation. Hypertension 41 882-890.

Eguchi S, Iwasaki H, Ueno H, Frank GD, Motley ED, Eguchi K, Marumo F, Hirata Y \& Inagami T 1999 Intracellular signaling of angiotensin II-induced p70 S6 kinase phosphorylation at Ser(411) in vascular smooth muscle cells: possible requirement of epidermal growth factor receptor, Ras, extracellular signal regulated kinase, and Akt. Journal of Biological Chemistry 274 36843-36851. 
Ekokoski E, Webb TE, Simon J \& Tornquist K 2001 Mechanism of P2 receptor-evoked DNA synthesis in thyroid FRTL-5 cells. Journal of Cellular Physiology 187 166-175.

Ferrandi M, Molinari I, Barassi P, Minotti E, Bianchi G \& Ferrari P 2004 Organ hypertrophic signaling within caveolae membrane subdomains triggered by ouabain and antagonized by PST 2238. Journal of Biological Chemistry 279 33306-33314.

Florio T, Arena S, Thellung S, Iuliano R, Corsaro A, Massa A, Villa V, Pattarozzi A, Diana F, Fusco A et al. 2001 The activation of the phosphotyrosine phosphatase eta is responsible for the somatostatin inhibition of $\mathrm{PC} \mathrm{Cl} 3$ thyroid cell proliferation. Molecular Endocrinology 15 1838-1852.

Foti D, Damante G \& Rapoport B 1990 Studies on the role of c-fos in TSH-stimulated thyroid cell proliferation. Cellular and Molecular Biology 36 363-373.

Garcia-Caballero A, Olivares-Reyes JA, Catt KJ \& Garcia-Sainz JA 2001 Angiotensin AT(1) receptor phosphorylation and desensitization in a hepatic cell line: roles of protein kinase $\mathrm{c}$ and phosphoinositide 3-kinase. Molecular Pharmacology 59 576-585.

Geisterfer AA, Peach MJ \& Owens GK 1988 Angiotensin II induces hypertrophy, not hyperplasia, of cultured rat aortic smooth muscle cells. Circulation Research 62 749-756.

Gill GN, Ill CR \& Simonian MH 1977 Angiotensin stimulation of bovine adrenocortical cell growth. PNAS $\mathbf{7 4}$ 5569-5573.

Grana X \& Reddy EP 1995 Cell cycle control in mammalian cells: role ofcyclins, cyclin dependent kinases (CDKs), growth suppressor genes and cyclindependent kinase inhibitors (CKIs). Oncogene 11 211-219.

Heinrich R \& Kraiem Z 1997 The protein kinase A pathway inhibits c-jun and $\mathrm{c}$-fos protooncogene expression induced by the protein kinase $\mathrm{C}$ and tyrosine kinase pathways in cultured human thyroid follicles. Journal of Clinical Endocrinology and Metabolism 82 1839-1844.

Herschman HR 1991 Primary response genes induced by growth factors and tumor promoters. Annual Review of Biochemistry 60 281-319.

Huber GK, Safirstein R, Neufeld D \& Davies TF 1991 Thyrotropin receptor autoantibodies induce human thyroid cell growth and c-fos activation. Journal of Clinical Endocrinology and Metabolism 72 1142-1147.

Isozaki O \& Kohn LD 1987 Control of c-fos and c-myc proto-oncogene induction in rat thyroid cells in culture. Molecular Endocrinology $1839-848$.

Krude T, Jackman M, Pines J \& Laskey RA 1997 Cyclin/Cdk-dependentinitiation of DNA replication in a human cell-free system. Cell 88 109-119.

Liang J, Zubovitz J, Petrocelli T, Kotchetkov R, Connor MK, Han K, Lee JH, Ciarallo S, Catzavelos C, Beniston R et al. $2002 \mathrm{PKB} / \mathrm{Akt}$ phosphorylates p27, impairs nuclear import of p27 and opposes p-27 mediates G1 arrest. Nature Medicine 8 1153-1160.

Marrero MB, Schieffer B, Li B, Sun J, Harp JB \& Ling BN 1997 Role of Januskinase/signal transducer and activator of transcription and mitogenactivated protein kinase cascades in angiotensin II- and platelet-derivedgrowth factor-induced vascular smooth muscle cell proliferation. Journal of Biological Chemistry 272 24684-24690.

Marsigliante S, Muscella A, Elia MG, Greco S \& Storelli C 2003 Angiotensin II receptor stimulates $\mathrm{Na}^{+}-\mathrm{K}^{+}$ATPase activity through a pathway involving PKC- $\zeta$ in rat thyroid cells. Journal of Physiology 2 461-470.

Martiny-Baron G, Kazanietz MG, Mischak H, Blumberg PM, Kochs G, Hug H, Marme D \& Schachtele C 1993 Selective inhibition of protein kinase C isozymes by the indolocarbazole Gö6976. Journal of Biological Chemistry 268 9194-9197.

Montiel M \& Jimenez E 1998 Characterization of angiotensin II receptors (binding and $\mathrm{m}-\mathrm{Rna}$ ) in the rat thyroid gland. Journal of Molecular Endocrinology 20 299-304.

Montiel M, Jimenez E, Narvaez JA \& Morell M 1984 Aldosterone and plasma renin activity in hyperthyroid rats: effect of propanolol and propylthiouracil. Journal of Endocrinological Investigation 7 559-562.

Morgan DO 1995 Principles of CDK regulation. Nature 374 131-134.

Mosmann T 1983 Rapid colorimetric assay for cellular growth and survival: application to proliferation and cytotoxicity assays. Journal of Immunological Methods 65 55-63.
Muscella A, Greco S, Elia MG, Storelli C \& Marsigliante S 2002 Angiotensin II stimulation of $\mathrm{Na}^{+} / \mathrm{K}^{+}$ATPase activity and cell growth by calciumindependent pathway in MCF-7 breast cancer cells. Journal of Endocrinology 173 315-323.

Muscella A, Greco S, Elia MG, Storelli C \& Marsigliante S 2004 Differential signalling of purinoceptors in HeLa cells through the extracellular signalregulated kinase and protein kinase C pathways. Journal of Cellular Physiology $200428-439$.

Naftilan AJ, Pratt RE \& Dzau VJ 1989 Induction of platelet-derived growth factor A-chain and c-myc gene expression by angiotensin II in cultured rat vascular smooth muscle cells. Journal of Clinical Investigation 83 1419-1424.

Naftilan AJ, Gilliland GK, Eldridge CS \& Kraft AS 1990 Induction of proto-oncogene c-jun by angiotensin II. Molecular and Cellular Biology $105536-5540$

Ohtsubo M, Theodoras AM, Schumacher J, Roberts JM \& Pagano M 1995 Human cyclin E, a nuclear protein essential for the G1-to-S phase transition. Molecular and Cellular Biology 15 2612-2624.

Pardee AB 1989 G1 events and regulation of cell proliferation. Science $\mathbf{2 4 6}$ 603-608.

Rolz W, Xin C, Ren S, Pfeilschifter J \& Huwiler A 2002 Interleukin-1 inhibits angiotensin II-stimulated protein kinase B pathway in renal mesangial cells via the inducible nitric oxide synthase. European Journal of Pharmacology 442 195-203.

Rosenberg ME \& Hostetter TH 1993 Effect of angiotensin II and norepinephrine on early growth response genes in the rat kidney. Kidney International 43 601-609.

Ruiz M, Montiel M, Jimenez E \& Morell M 1987 Effect of thyroid hormones on angiotesinogen production in the rat in vivo and in vitro. Journal of Endocrinology 115 311-315.

Saward L \& Zahradka P 1997 Angiotensin II activates phosphatidylinositol 3-kinase in vascular smooth muscle cells. Circulation Research 81 249-257. Sherr CJ 1994 G1 phase progression: cycling on cue. Cell 79 551-555. Sherr CJ \& Roberts JM 1995 Inhibitors of mammalian G1 cyclindependentkinases. Genes and Development 9 1149-1163.

Takahashi T, Taniguchi T, Konishi H, Kikkawa U, Ishikawa Y \& Yokoyama M 1999 Activation of Akt/protein kinase B after stimulation with angiotensin II in vascular smooth muscle cells. American Journal of Physiology 276 H1927-H1934.

Taubman MB, Berk BC, Izumo S, Tsuda T, Alexander RW \& Nadal-Ginard B 1989 Angiotensin II induces c-fos mRNA in aortic smooth muscle.. Journal of Biological Chemistry 264 526-530.

Tominaga T, Dela Cruz J, Burrow GN \& Meinkoth JL 1994 Divergent patterns of immediate early gene expression in response to thyroidstimulating hormone and insulin-like growth factor I in Wistar rat thyrocytes. Endocrinology 135 1212-1219.

Wagstaff SC, Bowler WB, Gallagher JA \& Hipskind RA 2000 Extracellular ATP activates multiple signalling pathways and potentiates growth factorinduced c-fos gene expression in MCF-7 breast cancer cells. Carcinogenesis 21 2175-2181.

Wolf G \& Wenzel UO 2003 Angiotensin II and cell cycle regulation. Hypertension 43 1-6.

Yang H \& Raizada MK 1999 Role of phosphatidylinositol 3-kinase in angiotensin II regulation of norepinephrine neuromodulation in brain neurons of the spontaneously hypertensive rat. Journal of Neuroscience 19 2413-2423.

Received in final form 4 August 2006

Accepted 21 August 2006

Made available online as an Accepted Preprint 28 September 2006 